\title{
Study of a Monsoon Depression (I)
}

\author{
Synoptic Structure
}

\author{
By T. N. Krishnamurti, Masao Kanamitsu, Ramesh Godbole, Chia-Bo Chang, \\ Fred Carr and Julianna H. Chow
}

Department of Meteorology Florida State University

(Manuscript received 3 March 1975, in revised form 15 May 1975)

\begin{abstract}
This is an observational study of a monsoon depression during its westward passage across India. We present a study based on available conventional radiosonde rawinsonde pilot balloon and commercial aircraft wind reports during August, 1968. Besides showing conventional analysis of the motion and thermal fields, we also show a number of vertical structure diagrams. The important findings of the observational study are that the horizontal scale of the depression is about $2000 \mathrm{~km}$, the vertical scale about $10 \mathrm{~km}$, its westward speed of motion about $5^{\circ}$ longitude /day. The monsoon depression is an intense closed vortex that has horizontal wind speeds of about 10 to $15 \mathrm{mps}$ and its closed circulation extends to about $9 \mathrm{~km}$ in the vertical. A narrow vertical tube of cyclonic vorticity with a horizontal scale $\approx 1000 \mathrm{~km}$ and extending up to $9 \mathrm{~km}$ is a characteristic feature of this circulation. This depresson formed over the northern part of the Bay of Bengal and dissipated over the Arabian Sea. The vortex has a very well defined cold core in the lower troposphere and a warm core above $500 \mathrm{mb}$. To the west of the cold core there exists a very intense warm core in the lower troposphere. The intense warm core is a consequence of advection of desert air by the storm circulation. Vertical motions show rising motion west of i.e., ahead of the trough line and descending motion to the rear. The westward motion of the monsoon depression is related to intense low level convergence in the region of the strongest ascending motion. In this region rainfall rates exceed $10 \mathrm{~cm} / 24 \mathrm{hrs}$ during the passage of the disturbance.

The analysis and observational structure derived in this study is examined in a second part of this paper, where the dynamics, energetics, and numerical prediction aspects are stressed.
\end{abstract}

\section{Introduction}

This is a two part paper on the structure, dynamics, and short range numerical weather prediction of a westward propagating monsoon depression over South Asia. The first part of the paper is primarily devoted to the observed structure of this disturbance. Monsoon depressions are known to form over the northern part of the Bay of Bengal during the months June through October. Long term statistics of the frequency of these disturbances suggest that about two disturbances per month form and usually move northwestwards, although some of these have been known to move northwards or due westwards. In the literature only a limited discussion of a few case studies on the monsoon depressions can be found. It is generally felt that due to sparcity of observations no definitive studies on the dynamics and structure have been possible, e.g., Rao and Rajamani (1972), Koteswaram and George (1958), and Pisharoty and Asnani (1957). These depressions form over the Bay of Bengal where satellite photographs show that cloud cover is usually present. It is felt that air-sea interaction and some form of a CISK mechanism might be important in the formative stages. It is also conceivable that the initial increase of eddy kinetic energy may be due to dynamical instability mechanisms such as (i) pure barotropic instability or (ii) perhaps a combined instability where baroclinic mechanisms are also important. A systematic analysis of this problem should be possible during MONEX (Monsoon Experiment, 1979). In the early planning of MONEX, which is in conjunction with the First GARP Global Experiment (FGGE), understanding of the formation of monsoon depressions is stated as one of the principal 
objectives.

In this paper we shall examine the structure of a monsoon depression as it propagates across India. We shall also attempt to contrast this structure with several other tropical disturbances that have appeared in literature.

The disturbance we studied formed over the northern part of the Bay of Bengal around the 2nd of August, 1968. The scale of the disturbance was very small $(\approx 1,000 \mathrm{~km})$ during the initial stages. It was not possible to obtain a definable structure on the 3rd of August when the depression had just moved inland. During the three following days, the disturbance moved roughly due westward and the center of the surface low was located near $20^{\circ} \mathrm{N}$ latitude. The rainfall rates in this disturbance were fairly large, 24 hourly totals exceeded $10 \mathrm{~cm}$ in the first $24 \mathrm{hrs}$ and exceeded $20 \mathrm{~cm}$ during the subsequent 24 hour period. The region of large rainfall rates was located slightly to the west of the surface low pressure center. The disturbance moved westward at a speed of roughly $5^{\circ}$ longitude per day. Synoptic experience has also suggested that monsoon depressions that move rapidly usually have rather intense precipita- tion rates ahead of them. The inevitable question of data coverage in the present study of the monsoon depression arises. The three observational platforms: pilot balloon network, rawinsonde network and commercial aircraft wind data above $30,000 \mathrm{ft}$ level were roughly distributed, over India as follows:

(i) Pilot balloon: out of maximum possible 56 sites about 40 observations per map time reached the $700 \mathrm{mb}$ surface.

(ii) Radiosonde: out of maximum possible 17 sites about 10 observations per map time reached $200 \mathrm{mb}$ surface.

(iii) Commercial aircraft winds: roughly 40 wind reports above $30,000 \mathrm{ft}$ level at the observation time $\pm 6 \mathrm{hrs}$ were available.

We shall now examine the pressure, wind and thermal fields from synoptic weather maps for the three map times between the 4th and 6th of August, 1968.

2. Synoptic Structure of the Monsoon Depression a) Surface Pressure

It is important to distinguish between the planetary scale monsoon trough and the synoptic

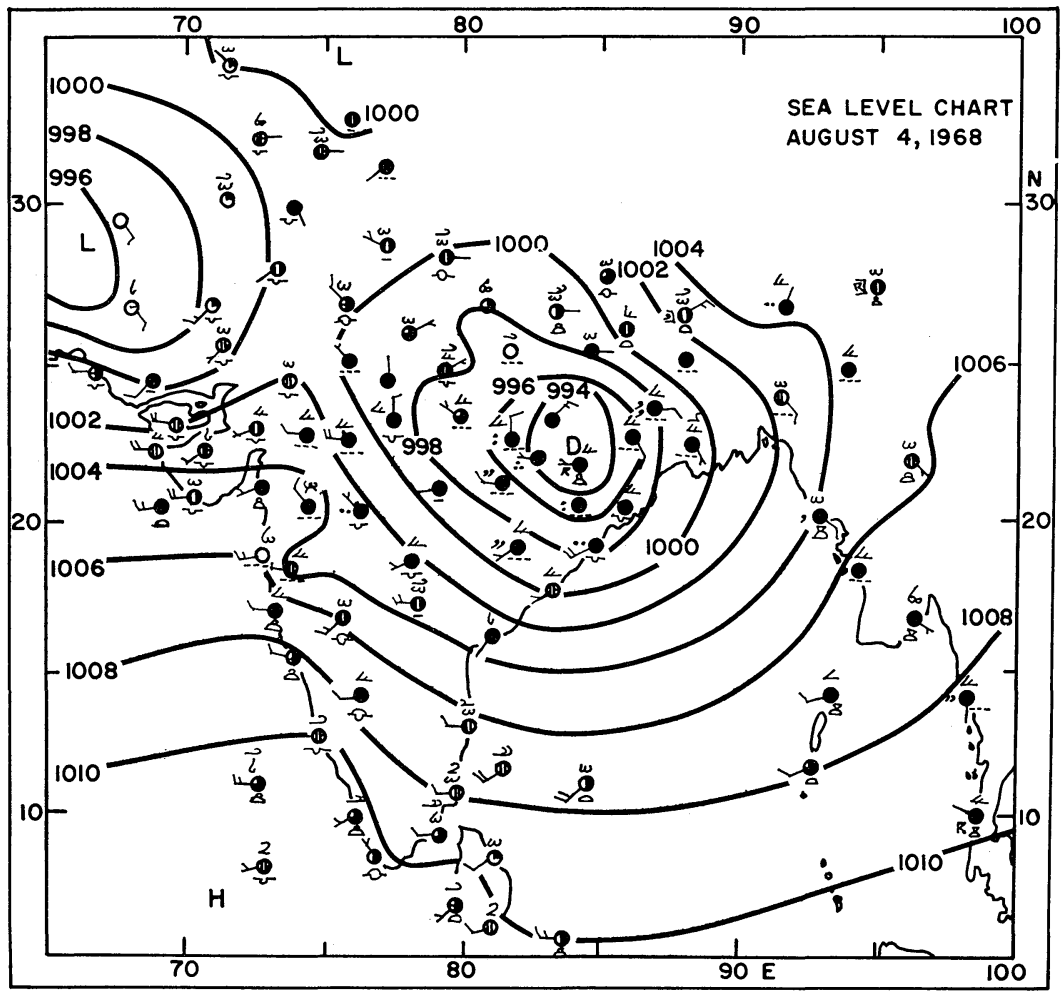

Fig. 1 (a). 


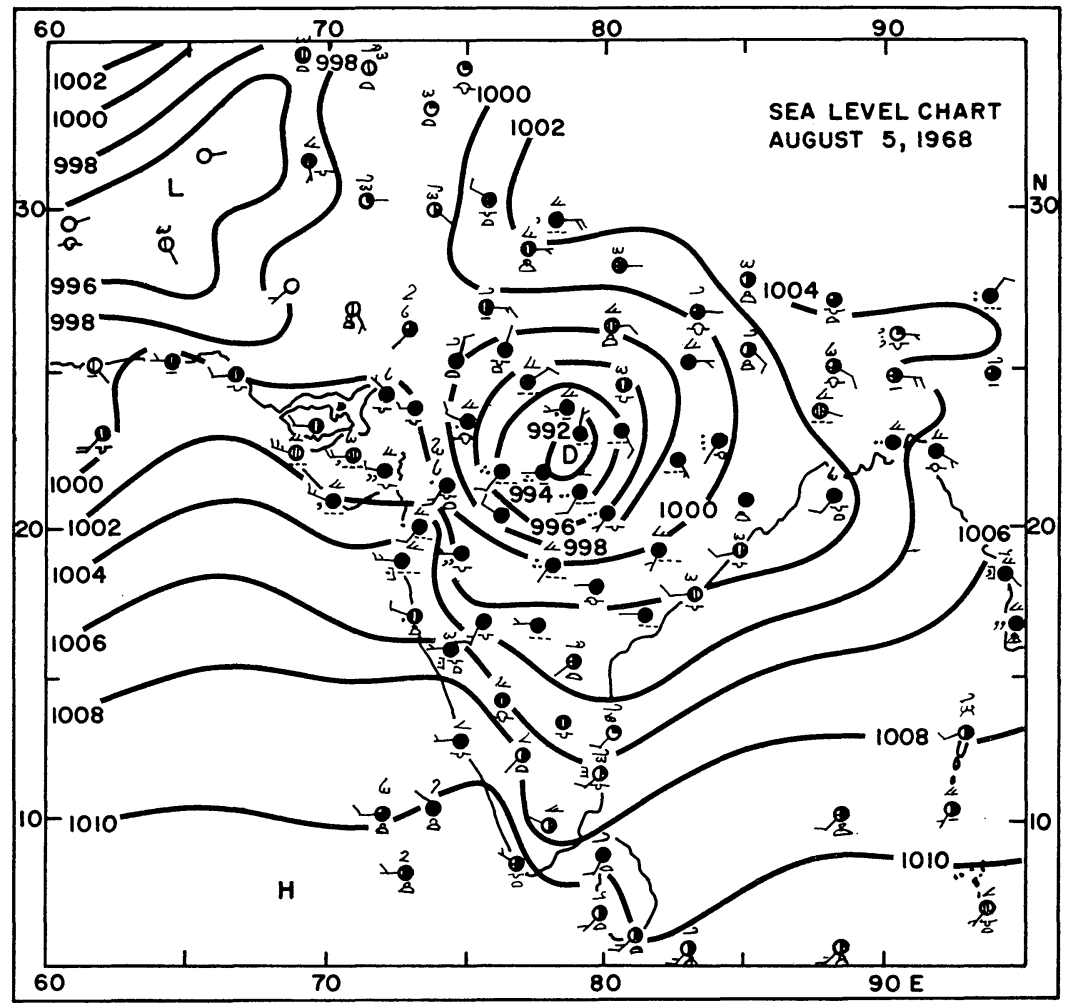

Fig. 1 (b).

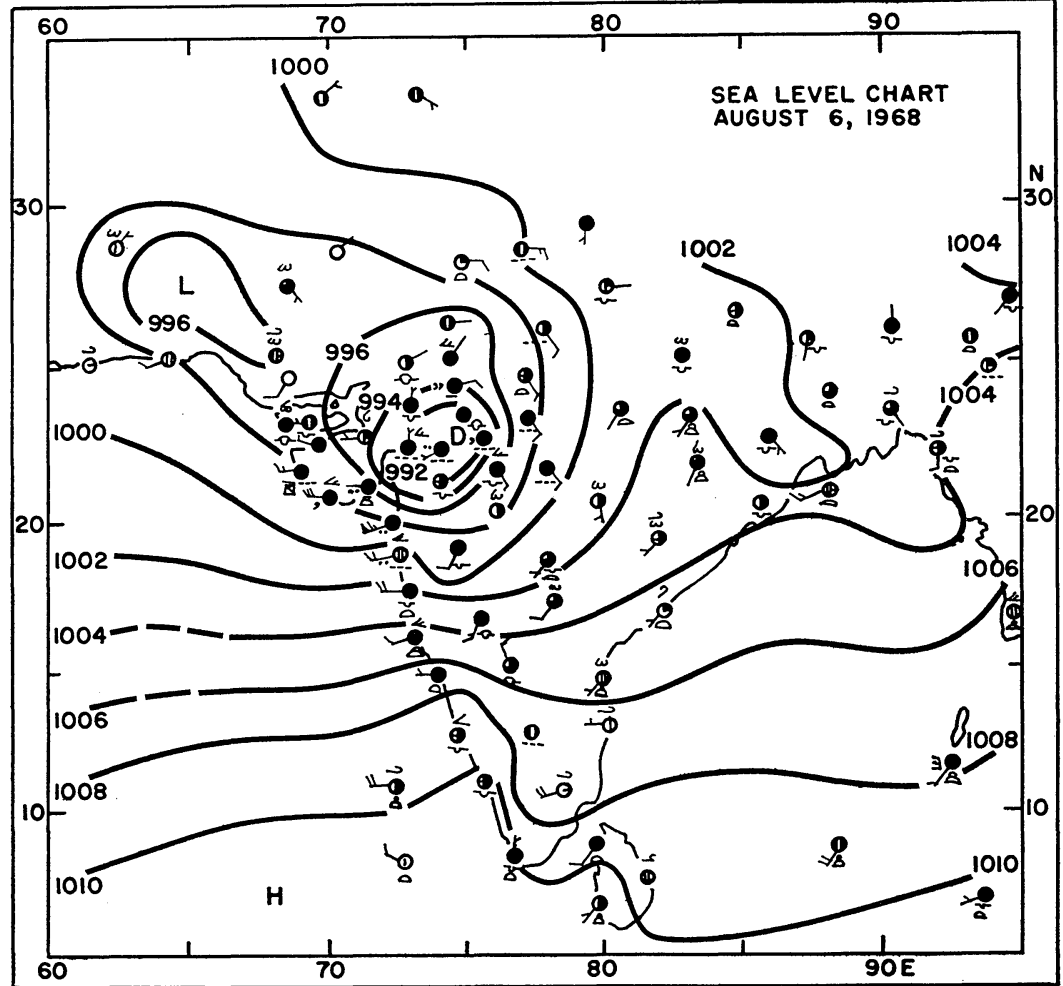

Fig. 1 (c).

Fig. 1. Surface pressure maps (mb) for $00 \mathrm{Z}$ 4, 5, 6 August, 1968. 
scale monsoon depression in the surface pressure geometry. The former has pressure of roughly $995 \mathrm{mb}$ and this system usually extends from the west coast of Africa to the Pacific coast of Asia. Over India this planetary scale trough has an axis oriented from the northwest to the southeast. Fig. 1 illustrates the surface pressure field for a sequence of three days. The synoptic scale monsoon depression with a central pressure of around $992 \mathrm{mb}$ propagates westward with a speed of roughly $5^{\circ}$ longitude/day in this sequence. This depression is similar to those over the tropical Atlantic and Pacific Oceans, many of which are known to become typhoons. The question naturally arises as to why these depressions do not become intense storms. One important reason is that the monsoon depression forms very close to land and moves inland soon after its formation. It is also felt that very strong vertical wind shear (low level westerlies and upper tropospheric easterlies) may be a strong inhibiting factor in their further development. The surface weather code (Fig. 1) shows that convective clouds dominate in the earlier history of this depression. As the disturbance approaches the west coast of India, more and more stratiform clouds are noted in the surface reports.

\section{b. Motion field at $850 \mathrm{mb}$}

The flow field at $850 \mathrm{mb}$ during the passage of the monsoon depression is illustrated in Fig. 2. Several details are of interest. To the south of the depression, there is a superposition of westerlies of the planetary scale monsoon flows and the flows associated with the depression; in this region strongest winds $(\approx 50$ knots $)$ may be noted. Initially strong winds are also noted to the northeast of the vortex center. In this region the easterlies of the monsoon trough and of the depression appear to superimpose. On the final day of this study, the strength of the easterlies diminishes somewhat as the depression moves westward and away from the axis of the planetary scale monsoon trough. The location of the axis of the planetary scale monsoon trough is determined by drawing the axis of the monsoon trough from a monthly mean surface pressure chart. The analysis of the depression at $850 \mathrm{mb}$ makes use of the rawinsonde observations as well as pilot balloon winds at the $1.5 \mathrm{~km}$ level. In this domain another disturbance is found to move in from the western Pacific Ocean, over the China Sea and
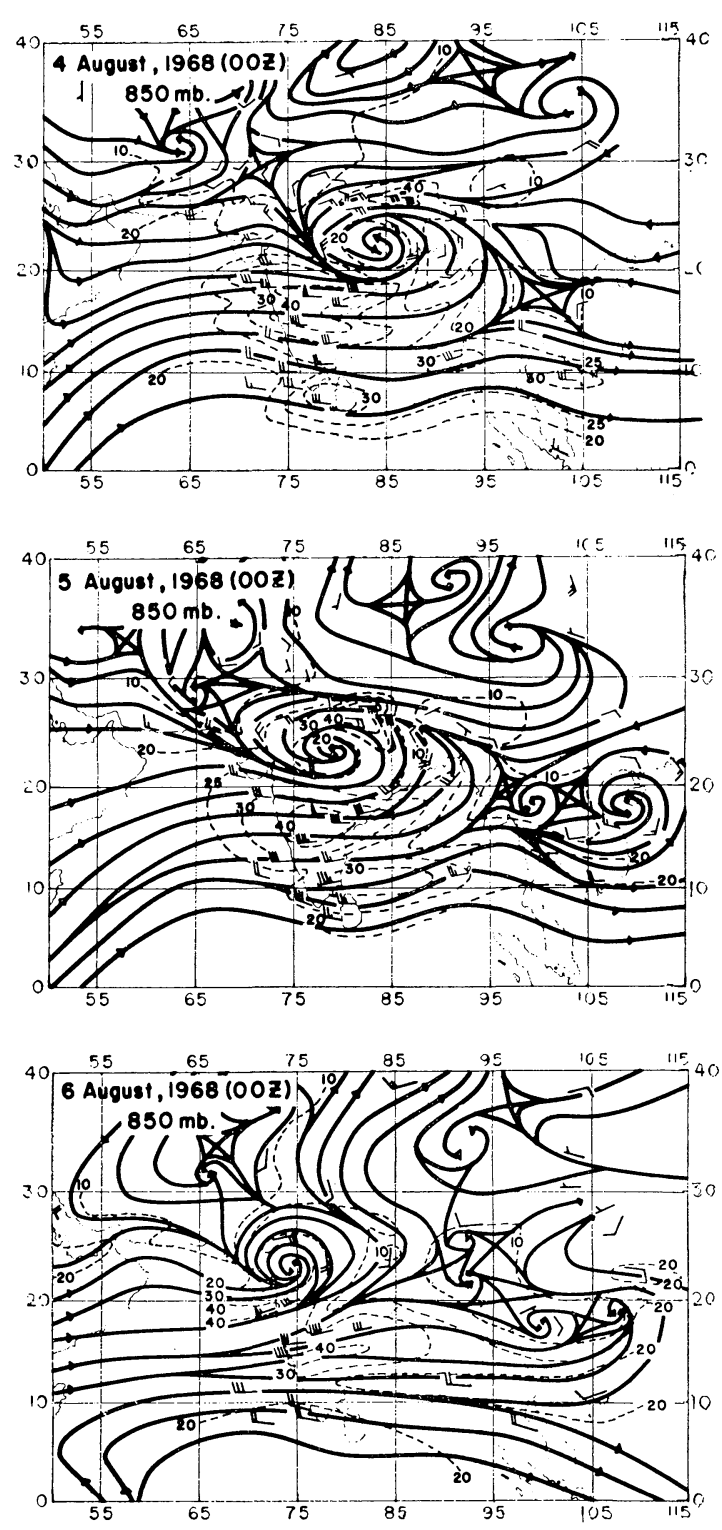

Fig. 2. Motion fields at $850 \mathrm{mb}$ for $4,5,6$ August, 1968.

towards Indochina. South of $10^{\circ} \mathrm{N}$ latitude, monsoon westerlies are persistent throughout the 3-day period. We, furthermore, noted that the strength of these monsoon westerlies over the southern region is somewhat stronger when there is a depression present over northern India. Our analysis north of $30^{\circ} \mathrm{N}$, where the elevation is very high, is not representative of $850 \mathrm{mb}$. This was done merely to provide completeness of the field in the domain. 


\section{c. Motion Field in the Middle and Upper Troposphere}

Due to data limitations, the analysis over this region is somewhat less reliable. Pilot balloon observations in the vicinity of the monsoon depression are not possible because of cloud cover. Away from the depression over northwestern India and over southern India, a few pilot balloon observations are available. We shall not show diagrams of flow at the $500 \mathrm{mb}$ surface. The vortex was clearly evident at this level. There was
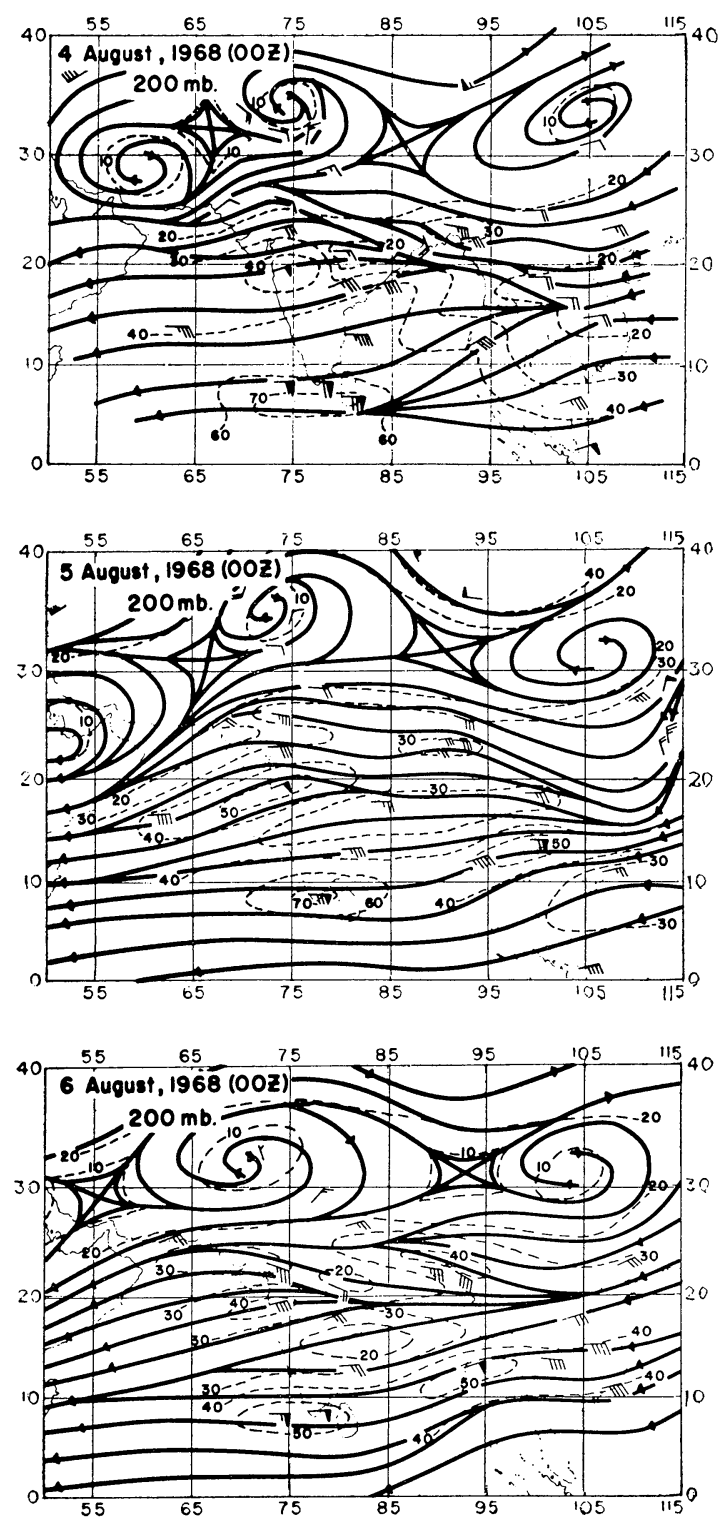

Fig. 3. Motion fields at $200 \mathrm{mb}$ for $4,5,6$ August, 1968. equatorward and eastward tilt with height of the system between the surface and the $500 \mathrm{mb}$ surface. When the monsoon depression approaches the west coast of India, the $500 \mathrm{mb}$ circulation resembles a typical midtropospheric cyclone (Miller and Keshavamurthy, 1968; Krishnamurti and Hawkins, 1971). The disturbance is known to dissipate in the eastern Arabian Sea which may be due to the advection of strong dry air from the deserts of Arabia into the disturbance in the middle levels. We shall discuss this feature in the numerical prediction of the monsoon depression.

The motion field at $200 \mathrm{mb}$ for the three map times is illustrated in Fig. 3. A branch of the tropical easterly jet is evident in the vicinity of Srilanka, i.e., near $10^{\circ} \mathrm{N}$ with speeds close to 70 knots. A minimum band of easterlies is found near $15^{\circ} \mathrm{N}$ and another belt of strong easterlies is found in the vicinity of $20^{\circ} \mathrm{N}$, north of which we note the large anticyclone belts. The monsoon depression does not appear to vertically extend to this level. The broad easterly current at $200 \mathrm{mb}$ appears to be similar, i.e., persistent on all three maps.

\section{d. Thermal Fields}

The time history of the observed potential temperature field at $900 \mathrm{mb}$ and at $500 \mathrm{mb}$ is shown in Fig. 4. The westward propagating cold core (marked C) of the thermal field at $900 \mathrm{mb}$ is very well defined. A strong thermal gradient to the west of the disturbance may be noted. As the monsoon depression propagates westwards warm advection of the Arabian air enhances the temperature gradient between the cold core and the warm desert air. This is one of the most pronounced thermal gradients for a tropical disturbance. The maintenance of this thermal gradient is an important scientific problem. Factors such as adiabatic ascent, evaporation of falling rain and radiative cooling may all be important for the understanding of the cold core. The intensity of the thermal field to the northwest in the desert air requires a detailed analysis of the heat balance of the earth's surface. These are topics that we shall examine in some detail in the second part of this paper. Rather pronounced warm and cold advection may be noted in the vicinity of this region of large thermal gradient. Pronounced warm advection to the west of the monsoon depression accounts partially for the observed up- 

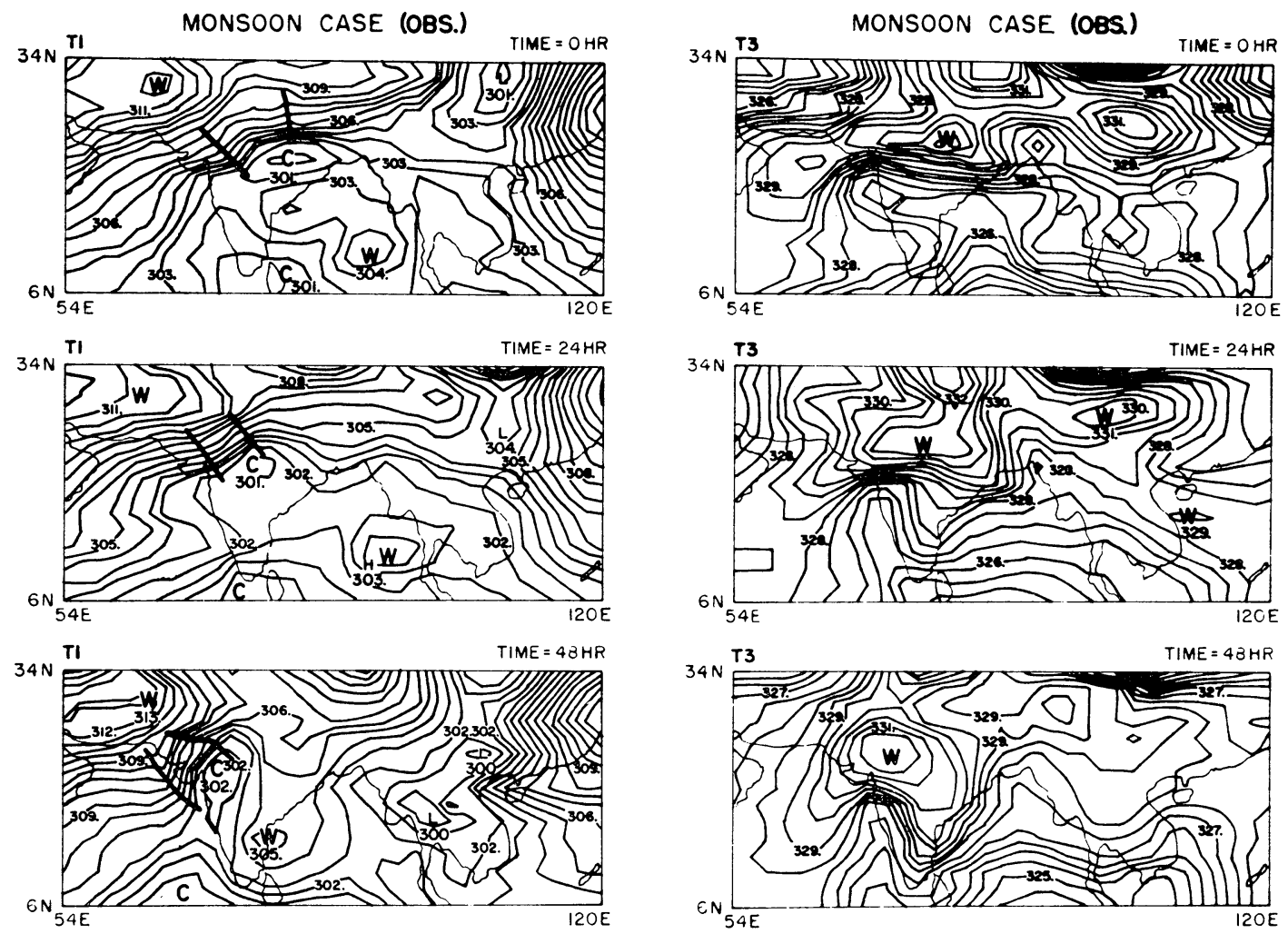

Fig. 4. Potential temperature fields $\left({ }^{\circ} \mathrm{K}\right)$ at $900 \mathrm{mb}$ and $500 \mathrm{mb}$. The intervals are $0.75^{\circ} \mathrm{K}$ for $900 \mathrm{mb}$ and $0.5^{\circ} \mathrm{K}$ for $500 \mathrm{mb}$.

ward motion and low level convergence. The monsoon depression propagates westward against the lower tropospheric broad scale southwest monsoon current. The westward motion is easy to understand if we recognize that a pronounced field of low level convergence lies to the west of the depression.

The potential temperature field at $500 \mathrm{mb}$ illustrates a warm pool of air to the north of $20^{\circ} \mathrm{N}$ (marked $\mathrm{W}$ ). This warm region has a very pronounced equatorward tilt with height. A warm core directly above the surface low is only found above $500 \mathrm{mb}$ (see Fig. 7). Although one might note many other thermal features in Fig. 4, it is sufficient to say that our interest here is in fields near the depression. At $500 \mathrm{mb}$ a rather pronounced thermal gradient is present to the south of the warm pool. A secondary tropical easterly jet near $20^{\circ} \mathrm{N}$ in Fig. 3 at $200 \mathrm{mb}$ is evidently related to this thermal gradient.

\section{Vertical Structure of the Monsoon Depression}

In this section we present vertical cross-sections passing through the center of the disturbances. Most of these vertical structures are shown on zonal vertical planes.

\section{a. Meridional Wind}

At $22^{\circ} \mathrm{N}$ we show a vertical cross-section of the meridional wind. This section intersects the storm's surface center during the three map times. The units are meters/sec. Plus signs show southerly motion and minus signs indicate northerly motions. The amplitude of the meridional wind is roughly $8 \mathrm{mps}$. The maximum intensity of the northerly flows is found near the $600 \mathrm{mb}$ surface. During the westward passage of the monsoon depression across India, the level of maximum southerly flows is found to descend from $600 \mathrm{mb}$ to the surface. The monsoon depression is, in fact, a vortex whose cyclonic circulation extends from the surface up to $300 \mathrm{mb}$. This is evidenced from examination of the meridional as well as zonal wind cross-sections (presented in the following section). In the domain presented here, during the westward passage of the monsoon 


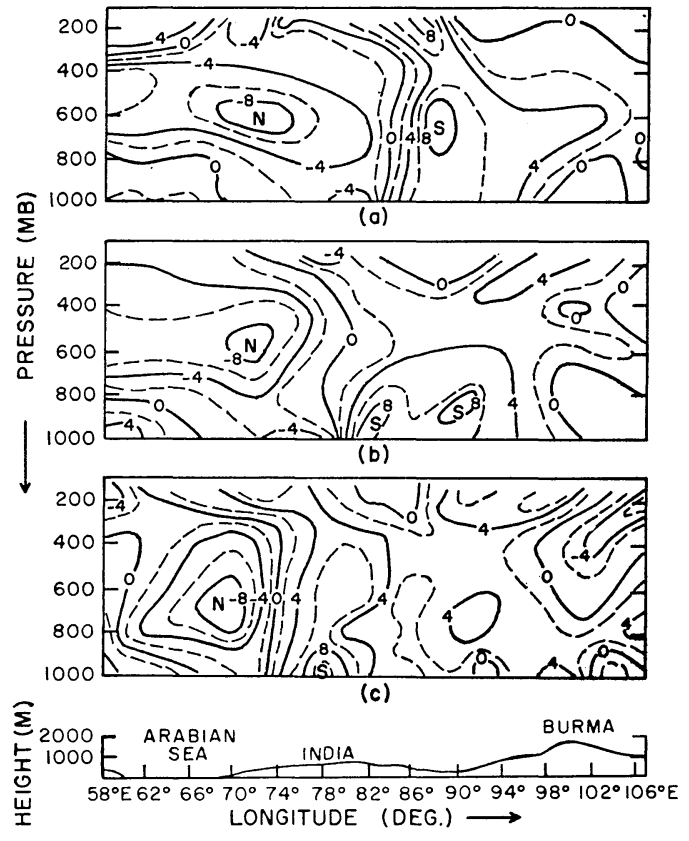

Fig. 5. Vertical cross-section of meridional wind (m/s) along $22^{\circ} \mathrm{N}$ for $4(\mathrm{a}), 5(\mathrm{~b})$, 6 (c) August, 1968.

depression, much of the region of the Arabian Sea encounters strong northerly flow of relatively warm air (Fig. 5). During the passage of the monsoon depression, there is a strong equatorward flux (down the gradient) of sensible heat $\left(\overline{v^{\prime} T^{\prime}}<0\right)$. We shall discuss the implication of this further in the second part of this study in the discussion of the energetics of the monsoon depression.

\section{b. Zonal Wind}

A vertical meridional cross-section of the zonal wind was prepared during the three map times (Fig. 6). These sections were again selected to pass through the surface center of the storm. The level of strong easterlies north of the depression lies near the $800 \mathrm{mb}$ surface and its intensity is close to $15 \mathrm{mps}$. The strength of the westerlies south of the storm is between 15 and $20 \mathrm{mps}$ and the level of the strongest westerlies descends from $800 \mathrm{mb}$ to the surface during the westward passage of the depression. Note that the three vertical cross-sections are prepared at $82^{\circ} \mathrm{E}, 76^{\circ} \mathrm{E}$ and $70^{\circ} \mathrm{E}$ during the three map times. In the vertical the influence of the storm may be noted up to $400 \mathrm{mb}$. Above this level a tropical easterly jet near $6^{\circ} \mathrm{N}$ may be noted.

Thus an examination of the zonal and

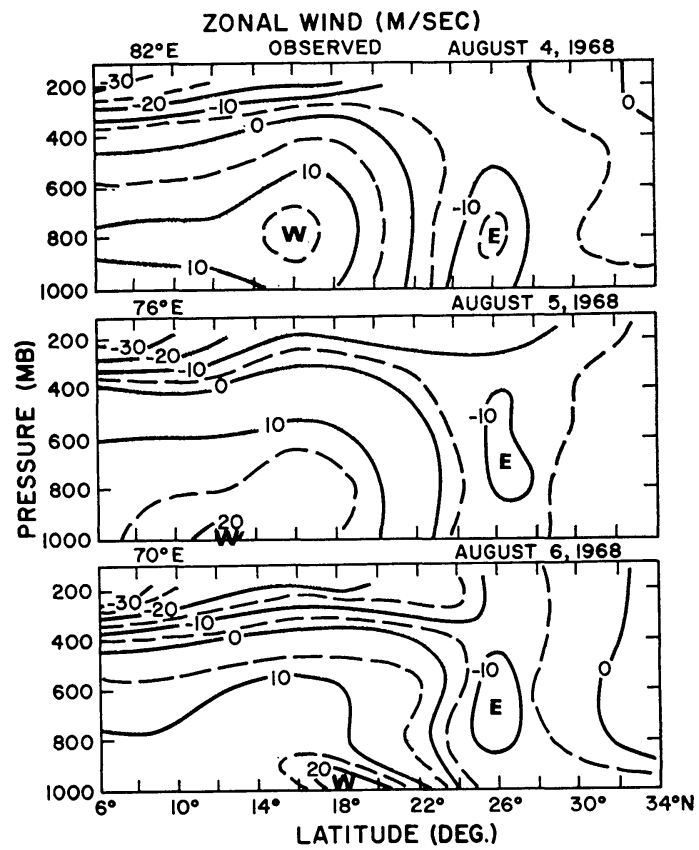

Fig. 6. Vertical cross-section of zonal wind $(\mathrm{m} / \mathrm{s})$ along $80^{\circ} \mathrm{E}, 76^{\circ} \mathrm{E}$ and $70^{\circ} \mathrm{E}$ for 4, 5, 6 August, 1968, respectively.

meridional wind cross-sections shows that the depression is a vigorous and deep tropospheric vortex whose circulation is strongest near the $800 \mathrm{mb}$ surface. The cross-sections furthermore suggest that the horizontal scale of the disturbance is of the order of $2500 \mathrm{~km}$ and its vertical scale about $10 \mathrm{~km}$.

\section{c. Thermal Structure}

Temperature anomaly is defined as a departure from a latitudinal average at a pressure level. The thermal structure is portrayed (Fig. 7) as a vertical cross-section along a latitude circle, $22^{\circ} \mathrm{N}$. This section passes roughly through the surface center of the monsoon depression during the three map times. The salient feature of the thermal structure is the cold core structure of the disturbance. The thermal amplitude of the monsoon depression is largest near $800 \mathrm{mb}$ (between 3 to $6^{\circ} \mathrm{C}$ ). A pronounced warm core ahead of the wave arises primarily from the low level warm advection of desert air west of the depression. The cold core is very pronounced below $600 \mathrm{mb}$ and there is a reversal of thermal structure above that level. The thermal amplitude of the disturbance in the upper troposphere near $400 \mathrm{mb}$ is only around 1 to $1.5^{\circ} \mathrm{C}$. There appears to be an 


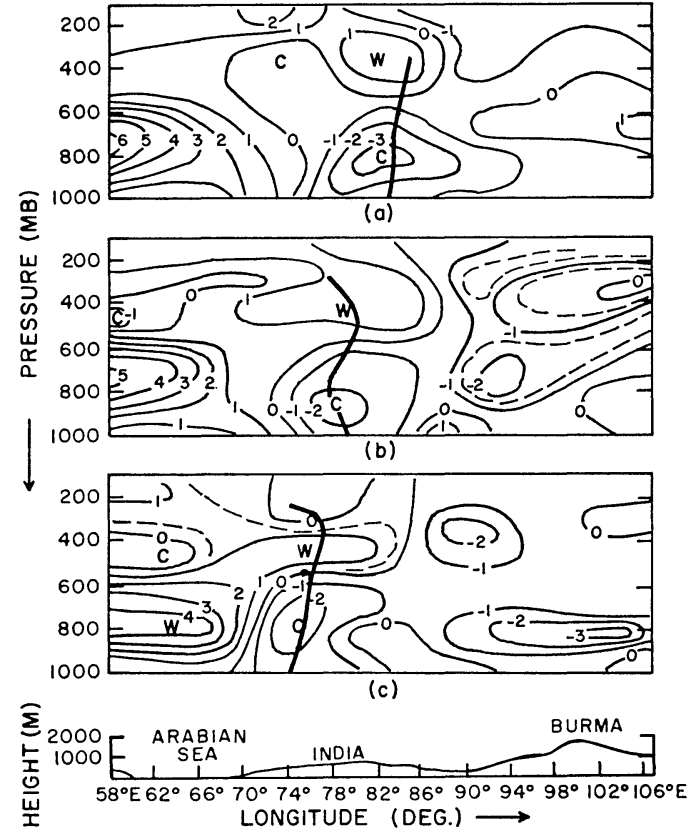

Fig. 7. Vertical cross-section of temperature anomaly $\left({ }^{\circ} \mathrm{C}\right)$ along $22^{\circ} \mathrm{N}$ for $4(\mathrm{a})$, 5 (b), 6 (c) August, 1968.

eastward tilt with height of the cold core. The thermal structure illustrated here is very unique in many respects. In part II of this paper, we shall discuss the significance of this structure with regards to the energetics of the disturbance. The correlation of vertical velocity and temperature $\left(\overline{\omega^{\prime} T^{\prime}}\right)$ and of convective heating and temperature $\left(\overline{H^{\prime} T^{\prime}}\right)$ are respectively important for the conversion of eddy available potential energy to eddy kinetic energy and the generation of eddy available potential energy from convection. It turns out that this pronounced thermal amplitude below $600 \mathrm{mb}$ makes these energy conversions rather unique. This thermal structure is furthermore quite different from that of a number of other tropical wave disturbances, e.g., Reed and Recker (1971) have presented the thermal structure of a composite easterly wave in the equatorial Pacific, Baumhefner (1968) presenfed structure of an easterly wave over the western Atlantic Ocean, Pedgley and Krishnamurti (1975) and Krishnamurti et al. (1975) have prepared thermal structures of African waves. The monsoon depression appears to have the most pronounced thermal amplitude among these. The oceanic disturbances have a thermal amplitude, in the lower troposphere, of the order of $1^{\circ} \mathrm{C}$ while the African wave has a

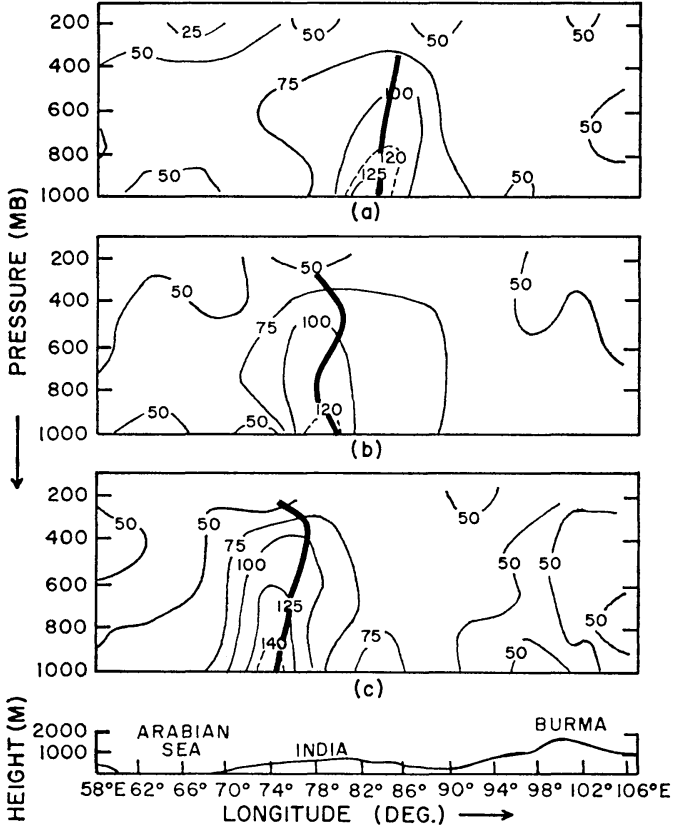

Fig. 8. Vertical cross-section of absolute vorticity $\left(10^{-6} \mathrm{~s}^{-1}\right)$ along $22^{\circ} \mathrm{N}$ for 4 (a), 5 (b), 6 (c) August, 1968.

corresponding amplitude on the order of $3^{\circ} \mathrm{C}$.

\section{d. Absolute Vorticity}

In Fig. 8 we show vertical cross-section of the absolute vorticity on a zonal plane $\left(22^{\circ} \mathrm{N}\right)$. The sections are portrayed for three map times during the westward passage of the monsoon depression. The isopleths of the absolute vorticity show that the disturbance is very vigorous (maximum value $\approx 1.4 \times 10^{-4} \mathrm{sec}^{-1}$ ). These values may be compared to those, e.g., obtained by Williams (1970) for a composite cloud cluster over the western Pacific Ocean. Although both of these show somewhat similar patterns i.e., vertical extent and horizontal scale), the maximum value in the latter is about $1 / 3$ that for the monsoon depression. It may be noted that the value of the coriolis parameter at $22^{\circ} \mathrm{N}$ is $\approx 0.55 \times 10^{-4} \mathrm{sec}^{-1}$. The largest value of the vorticity is near the surface. Surface vorticity increases somewhat (about 15\%) as the disturbance approaches the Arabian Sea. Precipitation rates in the last 24 hours also showed a marked increase (maximum rate $\approx 20 \mathrm{~cm} / 24 \mathrm{hrs}$ ) as the storm's surface vorticity increased. Daggupaty (1972) carried out an analysis of the terms of the vorticity equation to explain the westward passage of this disturbance. The westward passage of a 
monsoon depression is an interesting dynamical problem. His analysis shows that the convergence term of the vorticity equation is largest to the west of the disturbance, while the horizontal advection of absolute vorticity is largest to the east of the disturbance. Largest rainfall rates were also noted in the western and southwestern quadrants of the storm. The steering of the storm is thus a baroclinic phenomenon; barotropic concepts such as zonal flow steering, beta effect and positive vorticity advection do not account for the obseved westward motion.

\section{e. Vertical Structure of the Moisture Variable}

The presence of very dry desert air in the heat low over northwesterm India, Pakistan and Arabia results in a rather pronounced gradient of moisture across the monsoon depression. Unlike in other oceanic disturbances such as an easterly wave (e.g., Krishnamurti and Kanamitsu, 1973) the zonal gradient of moisture across the monsoon depression appears to be about 3 times larger. Fig. 9 illustrates vertical zonal cross-sections of the water vapor mixing ratio anomaly for the three map times. Of interest here is the moist region over India and the dry belt over the Arabian Sea. A fairly deep moist layer is seen

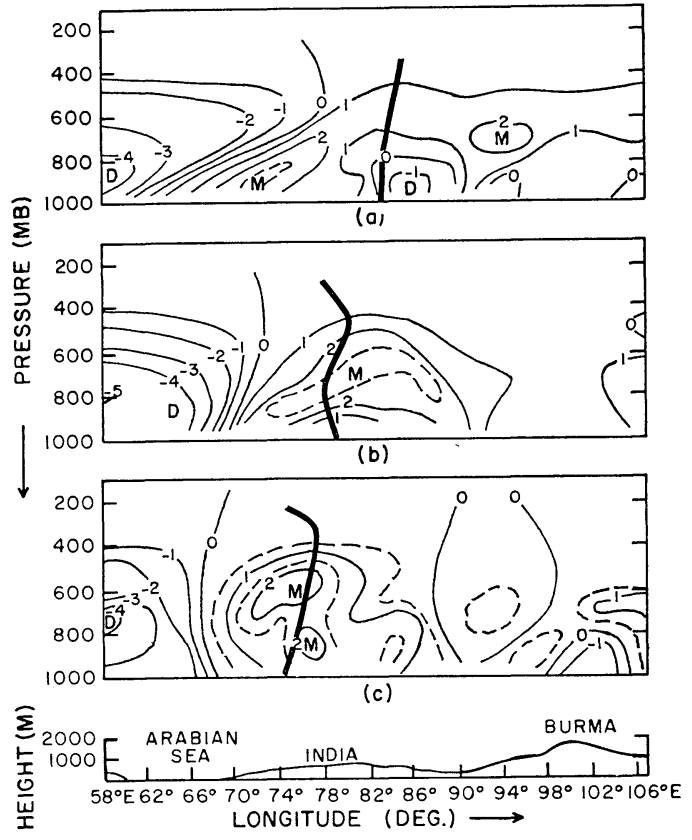

Fig. 9. Vertical cross-section of specific humidity $(\mathrm{g} / \mathrm{kg})$ along $22^{\circ} \mathrm{N}$ for 4 (a), 5 (b), 6 (c) August, 1968. to extend up to $400 \mathrm{mb}$ by the third map time. The amplitude of the moisture wave is several $\mathrm{gm} / \mathrm{kgm}$. The moisture field appears to undergo a considerable organization in the verical as the disturbance propagates westward across India. The zero line in the figure should be regarded as a separation line between the moist and dry air for the disturbance; the zero line, for the anomaly merely represents a zero departure from a zonal average at a pressure level. The east-west amplitude is largest near $800 \mathrm{mb}$ and not at the surface level. The reason for this is that vertical advection is usually largest above the $1000 \mathrm{mb}$ surface. These advective effects (on synoptic and subsynoptic scales) influence the distribution of the large scale moisture fields.

It is of interest to ask to what extent the portrayed moisture distribution reflects the general monsoon climatic humidity variation and to what extent it reflects the structure of the monsoon depression. As stated above, we noted a variation in the observed structure in the vertical distribution of the humidity variable (Fig. 9). We feel that the organizational period we refer to here, may perhaps reflect the dynamics of the monsoon depression. In the initial stages, top panel of Fig. 9, dynamic instability (combined barotropic-baroclinic) and convection appeared to be important in the maintenance of the depression, however later convection became all too dominant. The moisture distribution depends, to a large extent, on the organization of convection. The statement on the intensity of convection is based on the intensity of rainfall which increased to well over $20 \mathrm{~cm} / 24 \mathrm{hr}$ later in the storm's history. The structural change, especially that of the vertical distribution of the moisture variable, is dependent on the dynamical processes operating on the storm. Evidently this raises more questions than we have answered here. Again, we wish to state that some of the dynamical forcing on the depression are further elaborated in Part II of this study.

\section{f. Vertical Motions and Vertical Distribution of Convergence}

Diagnostic vertical motions were evaluated using (i) a non-linear balanced $\omega$-equation (Krishnamurti, 1968) and (ii) a kinematic method. Fig. 10 shows vertical cross-sections for the three map times on a zonal plane $\left(22^{\circ} \mathrm{N}\right)^{\circ}$ from the first method. The units for vertical motion are $10^{-2} \mathrm{mb} / \mathrm{sec}$. The intense precipitation in this system is perhaps 


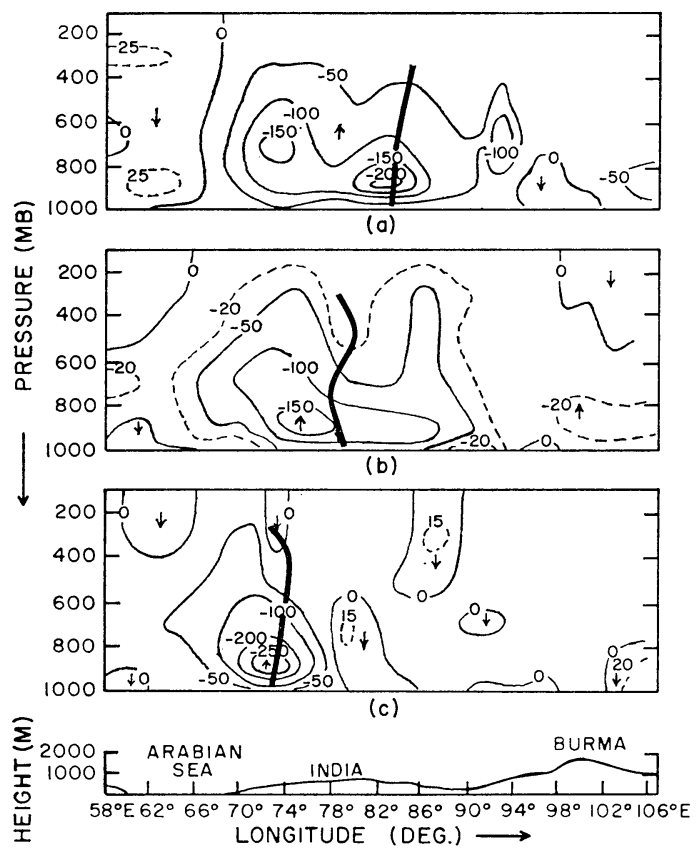

Fig. 10. Vertical cross-section of non-linear balanced $\omega\left(10^{-5} \mathrm{mb} / \mathrm{s}\right)$ along $22^{\circ} \mathrm{N}$ for 4 (a), 5 (b), 6 (c) August, 1968.

related to a rather low level of non-divergence, which was noted in both sets of calculations. The largest magnitudes are on the order of $-250 \times 10^{-5}$ $\mathrm{mb} / \mathrm{sec}$. It should be noted that this vertical distribution of vertical motion, $\omega$, and associated convergence (i.e., $\partial \omega / \partial p$ ) is model dependent. There appears to be a strong correlation between low level cyclonic vorticity and the rising motion locations. These vertical distributions of $\omega$ and $\partial \omega / \partial p$ are somewhat different from those obtained by Williams (1970) and Reed and Recker (1971) for the western Pacific cloud clusters. In these disturbances they noted lower and middle tropospheric regions of convergence and upper tropospheric horizontal divergence. The presence of a deep layer of convergence between the surface and $400 \mathrm{mb}$ has also been confirmed by other studies over the western Pacific. In our numerical diagnostic model the absence of midtropospheric convergence may be characteristic of the monsoon depressions.

The kinematic method usually suffers from large errors in the divergence distributions. The errors usually accumulate in the vertical integration of the mass continuity equation. Several remedies have been proposed by many authors to yield a zero value of the vertically integrated horizontal

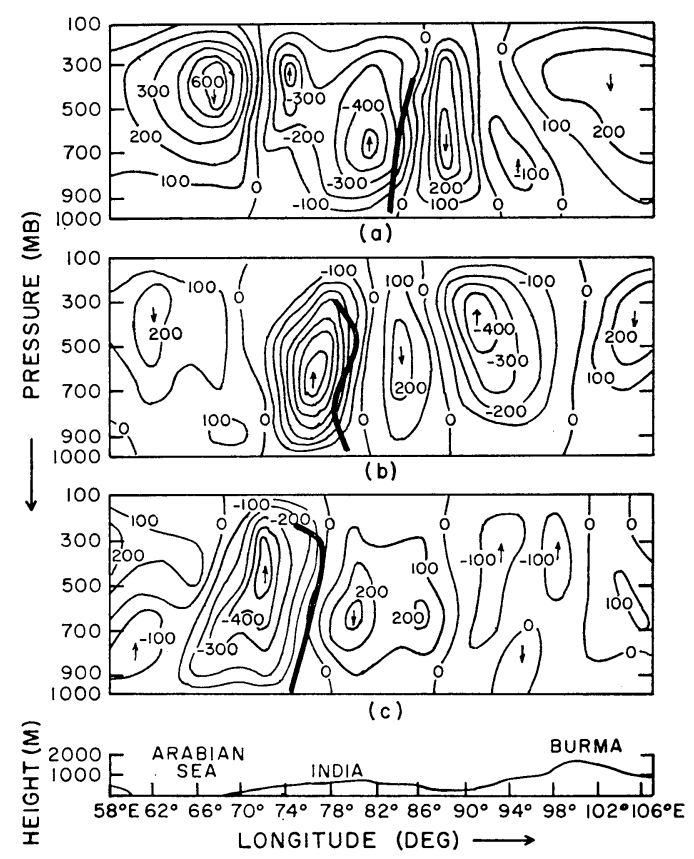

Fig. 11. Same as Fig. 10, obtained by the kinematic method.

divergence. We have used a simple linear correction technique which satisfies the above constraint as well as the two boundary conditions $\omega=0$ at $1000 \mathrm{mb}$ and $100 \mathrm{mb}$.

The kinematic vertical motions for the three days are shown in Fig. 11. A comparison of the results of the two methods is of interest. The major differences between these and the values from the balance models are: (i) The kinematic vertical motion values are two to three times larger. (ii) The level of non-divergence is slightly higher for the kinematic vertical motions, however they are still close to the $700 \mathrm{mb}$ surface for the first two days. (iii) There is a region of more pronounced subsidence over the Arabia Sea and just to the east of the depression. Both methods agree in the position of the maximum upward vertical velocity and the location of the vertical motion centers agrees well with the observed regions of rainfall in the monsoon depression.

Rao and Rajamani (1972) have also performed calculations of vertical motion for a monsoon depression. They noted a level of non-divergence around $700 \mathrm{mb}$ and rising motion centers to the west of the storm center. In the early and middle 1960's vertical motions were considered unreliable if one used the so-called kinematic 
method where the vertical integral of divergence had to be corrected. Dynamic vertical motions estimated via the use of the so-called non-linear or linearized versions of the omega equation did not require the vertical adjustment and were extensively used by a number of research groups. One noticed a large difference in the magnitudes of the vertical motions; the kinematic product over large sclae tropics was of the order of a few $\mathrm{cms} / \mathrm{sec}$. The dynamic vertical motions on the other hand were much smaller being of the order of about one $\mathrm{cm} / \mathrm{sec}$ or less. This discrepancy may also be noted in the vertical motions we present in this section. In the 1970's there has been a revival of interest in the kinematic method, especially by the budget balancing groups. It is very difficult to assess the discrepancy in simple terms. The dynamic vertical motions is model dependent and the prescription of the boundary layer dynamics, the surface stresses and such factors like the parameterization of cumulus convection determines the intensity of the vertical motions. Our numerical prediction model has a time dependent evolution of these physical effects and shows that the vertical motions lie somewhere in between the two extremes illustrated by the kinematic and the dynamic diagnostic methods. We feel that this question can only be resolved by much further study with better dynamical models.

\section{Monsoon Depression and other Tropical Disturbances}

We selected, somewhat arbitrarily a number of synoptic scale (few thousand $\mathrm{km}$ ) tropical disturbances that are well documented from the point of view of observational coverage. We show in Figs. 12 and 13, respectively, (a) the monthly mean zonal flows for the region where these were observed, and (b) their vertical structure. The third panel of charts (Fig. 13) shows the structure for the monsoon depression. It should be noted that although considerable variations in structure are usually found from one case study to the next, these are somewhat typical disturbances. The five disturbances illustrated, respectively are:

(i) Caribbean Easterly Wave, Baumhefner (1968).

(ii) African Monsoon Cyclone, Pedgley and Krishnamurti (1975).

(iii) Monsoon Depression over India. The present study.

(iv) Western Pacific Composite ITCZ Wave, Reed and Recker (1971)

(v) Eastern Pacific, Composite ITCZ Wave, Reed and Recker (1971).

The lower tropospheric westerlies of the south-

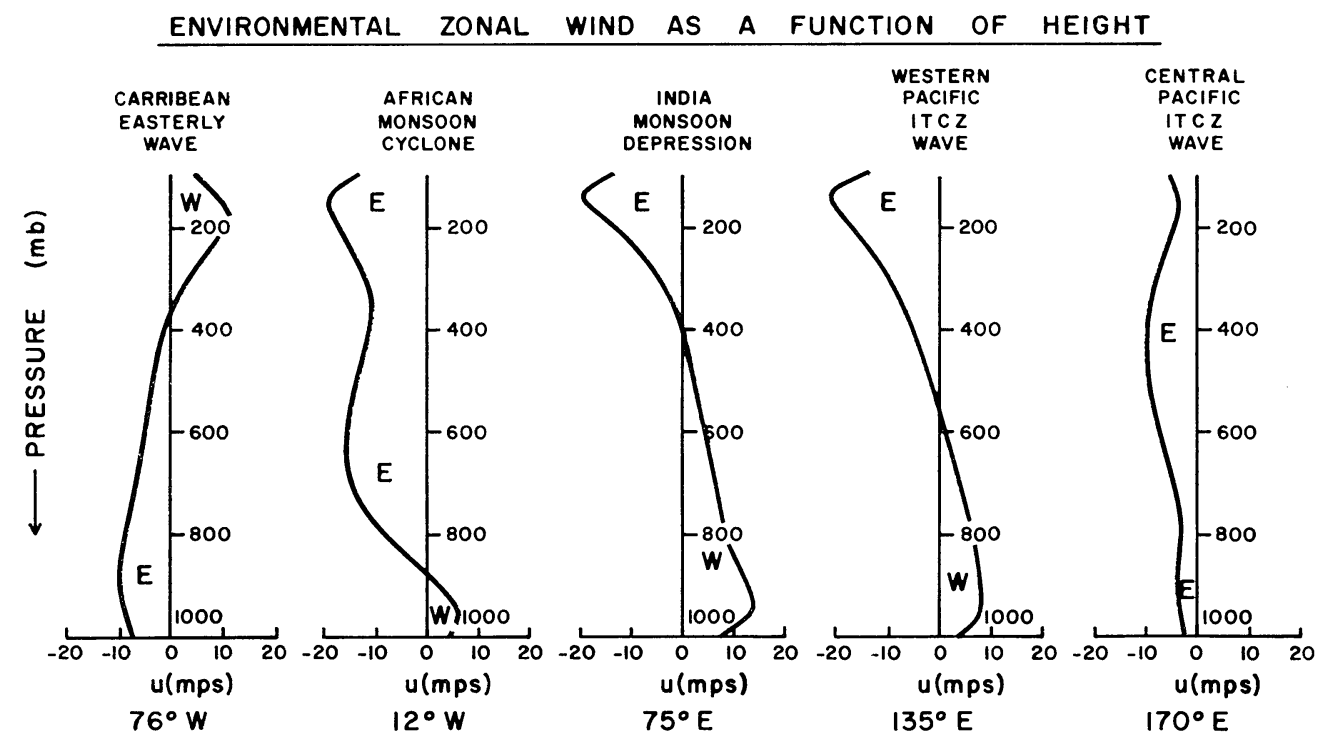

Fig. 12. Vertical profiles of monthly mean zonal wind in selected tropical regions where wave disturbances were analyzed. 

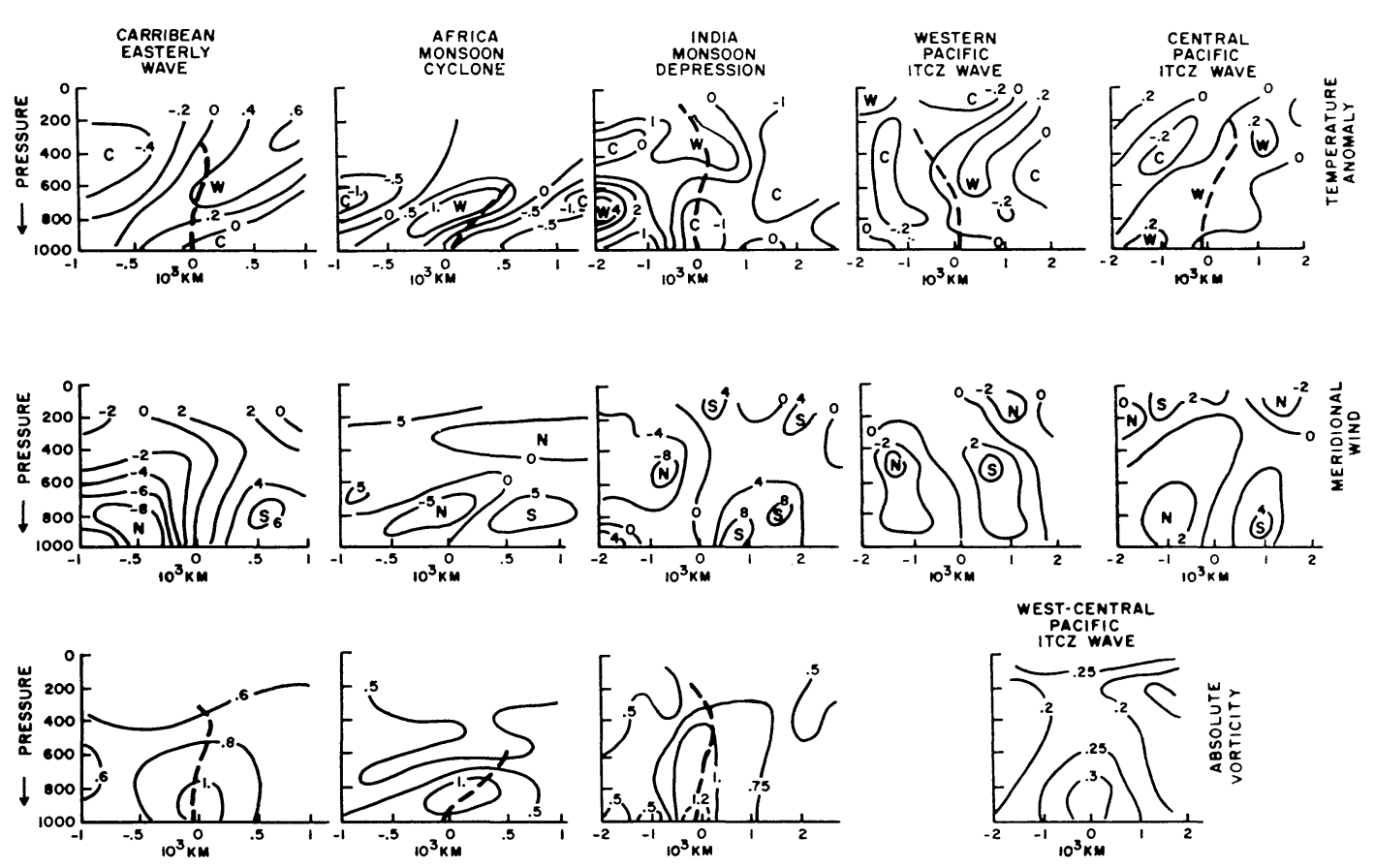

Fig. 13. Vertical structure diagrams of selected tropical disturbances. We show tem perature anomaly $\left({ }^{\circ} \mathrm{K}\right)$, meridional wind (mps), and absolute vorticity $\left(10^{-4} \mathrm{sec}^{-1}\right)$.

west monsoons may be noted (Fig. 12) from Africa to the western Pacific. It is quite evident that zonal flows and their vertical shear exhibit large zonal assymetry in the tropics. The environment in which one finds these is different. What is most common to these disturbances is that they all seem to propagate westward at about the same speed which is roughly $5^{\circ}$ to $7^{\circ}$ longitude per day. The vertical structure (Fig. 13) illustrates the temperature anomaly, meridional wind and absolute verticity for each of these disturbances.

The monsoon depression has the best defined cold core among these disturbances. Most disturbances show an eastward tilt with height of the thermal anomaly. The temperature amplitude is largest for the monsoon depression. The intensity of the meridional wind lies between 4 to $10 \mathrm{mps}$ in these disturbances. The maximum values of absolute vorticity for the Caribbean easterly wave, the African monsoon cyclone and the monsoon depression is about $1 \times 10^{-4} \mathrm{sec}^{-1}$. A cross-section of the absolute vorticity for the west central Pacific from Reed and Recker's study is shown in the bottom panel. The largest value here is shown to be about $0.3 \times 10^{-4} \mathrm{sec}^{-1}$. The latter result might be a slight underestimate because it is obtained for a composite wave. Furthermore, the latitude of this wave is around $7^{\circ} \mathrm{N}$ while the others shown in Fig. 13 occur near $15^{\circ}$ to $20^{\circ} \mathrm{N}$ latitude.

Convection and low level convergence appear to the east of the trough line for the Caribbean easterly wave and for the eastern Pacific ITCZ composite wave; for the remaining three monsoon disturbances these features were noted to the west of the trough line. Although this was the case for these typical case studies, considerable variations may be expected in other situations.

\section{Concluding Remarks}

In this paper we have obtained the synoptic structure of a westward propagating monsoon depression. The study is still not complete by any means, primarily because the definition during the formative stages of the depression is lacking. Furthermore, the structure presented here is limited by the available observations. During the forthcoming Monsoon Experiment (MONEX) during the First GARP Global Experiment (FGGE), we hope that better observations will become available to obtain a more definitive observational structure throughout the life cycle 
of the monsoon depression.

In the second part of this paper we shall deal with such topics as energetics, heat budget and numerical prediction with a hierarchy of models to understand the dynamics of the monsoon depression.

\section{Acknowledgments}

This work was supported by the Atmospheric Sciences Section of the National Science Foundation under Grant No. NSF GA-17822. Computational work was supported by the above grant at the Florida State University's CDC 6400 computer. Part of the computational work was also carried out at the National Center for Atmospheric Research on its CDC 6600, 7600 computer systems. The National Center for Atmospheric Research is sponsored by the National Science Foundation.

\section{References}

Baumhefner, D. P., 1968: Application of a diagnostic numerical model to the tropical atmosphere. Mon. Wea. Rev., 96, 218-228.

Daggupaty, S., 1972: A diagnostic study of monsoon depressions. Dept. of Meteorology, Florida State University. (Unpublished manuscript.)

Krishnamurti, T. N., 1968: A diagnostic balance model for studies of weather systems of low and high latitudes. Rossby number less than 1. Mon. Wea. Rev., 96, 197-207.

, and R. J. Hawkins, 1970: Midtropospheric cyclones of the southwest monsoons. J. Appl. Met., 9, 442-458. and M. Kanamitsu, 1973: A study of a coasting easterly wave. Tellus, 25, 568-585. , G. O. P. Obasi, C. B. Chang and M. Kanamitsu, 1975: On radiative interactions in an African disturbance. Tellus (submitted for publication).

Koteswaram, P. and C. A. George, 1958: A case study of a monsoon depression in the Bay of Bengal. Symposium on Monsoons of the World. Indian Meteorological Department, New Delhi, India, 145-156.

Miller, F. R. and R. N. Keshavamurthy, 1967: Structure of an Arabian Sea summer monsoon system. East-West Center Press, University of Hawaii, Honolulu, 94 pp.

Pedgley, D. E. and T. N. Krishnamurti, 1975: Structure and behavior of a monsoon cyclone over West Africa. Submitted to the Mon. Wea. Rev. for publication.

Pisharoty, P. R. and G. C. Asnani, 1957: Rainfall around monsoon depressions over India. Indian J. Meteor. and Geophys., 8, 15-20.

Rao, K. V. and S. Rajamani, 1972: Study of heat sources and sinks and the generation of available potential energy in the Indian region during the southwest monsoon season. Mon. Wea. Rev., 100, 383-388.

Reed, R. J. and E. E. Recker, 1971: Structure and properties of synoptic-scale wave disturbances in the equatorial Western Pacific. J. Atmos. Sci., 28, 1117-1133.

Williams, K. T., 1970: A statistical analysis of satellite observed trade wind cloud clusters in the western North Pacific. Rept. No. 161, Dept. of Atmos. Sci., Colorado State University, Fort Collins, pp. 1-80. 


\section{モンスーン低気压の研 究 (I)}

\section{啰乱構造の総観解析}

\section{T. N. Krishnamurti M. Kanamitsu R. Godbole C. B. Chang \\ F. Carr J. H. Chow}

インドを横切って西に移動するモンスーン低気圧の一例を総観的に研究した。この擾乱は1968年 8 月にベンガル湾 北部で発生し, アラビア海上で消隇したもので, その解析には通常のラジオン゙ンデやパイロットバルーン観測に加光, 旅客航空機による風の観測を用いた。研究にあたっては, 等圧面解析だけではなく, 数種の断面図解析を行った.

擾乱の水平スケールは約 $2000 \mathrm{~km}$, 垂直スケールは約 $10 \mathrm{~km}$ で, 1 日に経度にして約 5 度, 西に移動する.この 低気圧に伴う風速は 10 15 mps 飞達し, 低気圧性の渦度を持った強い渦動は直経 $1000 \mathrm{~km}$, 高さ $9 \mathrm{~km}$ に及ぶ. 温度構造は下層の非常に顕著な cold core と, $500 \mathrm{mb}$ より上層での warm core によって特徴ずけられる. 下層の cold core の西側では擾乱によって引き起された砂漠の高温な空気の移流による warm core がみられる. 擾乱の西 側（トラフの前面）には上昇気流, 東側 (後面) には下降気流があり, 西方への移動は上昇気流が最大の域にある下 層の強い convergence に関係している。この領域では擾乱の通過に伴う日降水量は $10 \mathrm{~cm}$ に達する.

第 2 部の論文では, この研究から得られた擾乱の構造を数值予報を用いて, 力学的, エネルギー的考察の観点から 調べる. 